\title{
Effect of dietary difructose anhydride III supplementation on bone mineral density and calcium metabolism in late-lactation dairy cows
}

\author{
Ayami MAETANI ${ }^{1,2) *}$, Masayuki OHTANI ${ }^{2)}$, Kaoru HATATE ${ }^{1,3)}$, \\ Kotaro MATSUMOTO ${ }^{1,3)}$ and Norio YAMAGISHI, ${ }^{1,3)}$ \\ 1)United Graduate School of Veterinary Sciences, Gifu University, 1-1 Yanagido, Gifu 501-1193, Japan \\ ${ }^{2)}$ Nippon Beet Sugar Manufacturing Co., Ltd., Obihiro, Hokkaido 080-0831, Japan \\ ${ }^{3)}$ Department of Veterinary Medicine, Obihiro University of Agriculture and Veterinary Medicine, Obihiro, \\ Hokkaido 080-8555, Japan
}

\section{J. Vet. Med. Sci. \\ 80(7): 1061-1067, 2018 \\ doi: 10.1292/jvms.17-0614}

Received: 14 November 2017 Accepted: 21 April 2018

Published online in J-STAGE: 14 May 2018

\begin{abstract}
The aim of the present study was to examine the effect of 28 days of dietary difructose anhydride (DFA) III supplementation on calcium (Ca) metabolism in late-lactation dairy cows. Twenty-four multiparous pregnant Holstein cows were divided into two groups. The DFA group was fed total mixed ration (TMR) supplemented with $40 \mathrm{~g}$ of DFA III, and the control group was fed TMR only. The replenishment of bone Ca reserves was evaluated by measuring bone mineral density (BMD) and blood biochemical bone markers. Serum Ca concentrations, urinary Ca-to-creatinine $(\mathrm{Cre})(\mathrm{Ca} / \mathrm{Cre})$ ratios, and milk Ca concentrations were also analyzed. The BMD of the 4th caudal vertebra in the DFA group was higher than in the control group on day 28. With respect to bone markers, the ratios of undercarboxylated osteocalcin (ucOC) to osteocalcin (OC) in the DFA group were significantly lower than those in the control group on days 21 and 28 . Milk Ca concentrations in the DFA group were also higher than those in the control group on days 14,21 , and 28 , whereas serum $\mathrm{Ca}$ concentrations and urinary $\mathrm{Ca} / \mathrm{Cre}$ ratios were unchanged in both groups. These results suggest that dietary supplementation with DFA III increased BMD and decreased serum ucOC/OC ratios in late-lactation dairy cows; this indicates that the replenishment of bone Ca reserves may be enhanced by dietary DFA III supplementation.
\end{abstract}

KEY WORDS: biochemical bone marker, bone mineral density, calcium metabolism, dairy cow, difructose anhydride III

Parturient dairy cows can develop varying degree of hypocalcemia during lactation due to the increased calcium (Ca) demands [9]. Previous studies have reported that bone mineral density (BMD) in dairy cows tends to decline as the cows get older, with the bone Ca reserves falling throughout early lactation and during replenishment in late lactation or dry period $[1,16,38]$. Liesegang et al. [16] have suggested that the parturient cows have increased bone resorption and mobilized Ca actively from the bone. Therefore, dairy cows experience with a dramatic challenge in Ca homeostasis and BMD from one parturition to the next. The replenishment of bone Ca reserves in late-lactation may be one of the potential factors that can aid in the prevention of BMD decline in dairy cows.

Difructose anhydride (DFA) III (di-D-fructofuranose-1,2':2,3c-dianhydride) is an indigestible oligosaccharide that is synthesized from inulin [13], and several investigations have suggested that it has positive effects on cows. The ruminal microorganisms have difficulty in digesting DFA III in dairy cows [30]. Therefore, approximately $70 \%$ of DFA III reaches the duodenum of the cows $4 \mathrm{hr}$ after feeding [33]. Furthermore, DFA III accelerates Ca absorption via the paracellular pathway in the bovine duodenum [33], and dietary DFA III supplementation likely promotes passive intestinal Ca absorption via the paracellular pathway in the early postpartum dairy cows [34]. Additionally, dietary DFA III improves the absorption of intestinal immunoglobulin G from the colostrum in newborn dairy calves [29] and enhances the overall health of Japanese Black calves [19, 32].

There is little information on dietary techniques that increase bone Ca reserves in late-lactation cows. We hypothesized that dietary DFA III supplementation in late-lactation can enhance replenishment of bone Ca reserves. The aim of the present study was to examine the effect of dietary DFA III supplementation for 28 days during late-lactation on Ca metabolism in dairy cows.

*Correspondence to: Maetani, A.: ayamidrlove0202@gmail.com

O2018 The Japanese Society of Veterinary Science

This is an open-access article distributed under the terms of the Creative Commons Attribution Non-Commercial No Derivatives (by-nc-nd) License. (CC-BY-NC-ND 4.0: https://creativecommons.org/licenses/by-nc-nd/4.o/) 

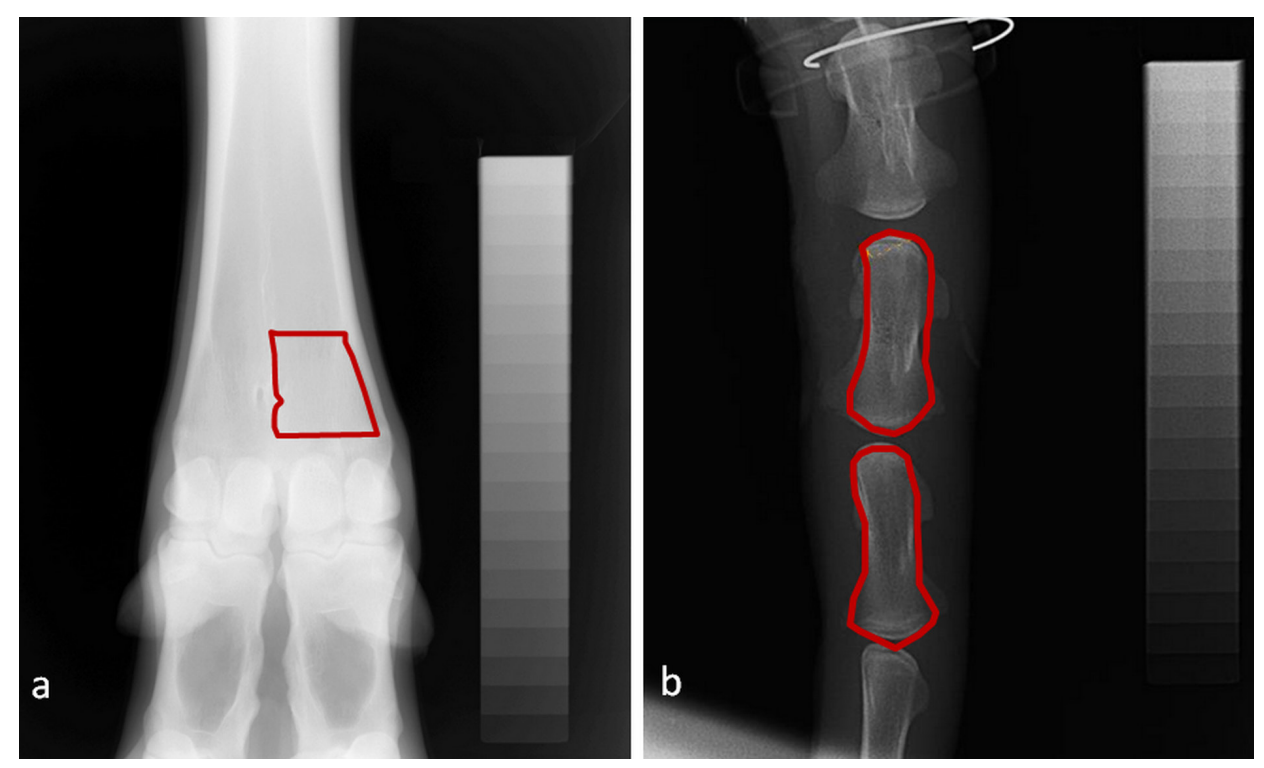

Fig. 1. Selected region of interest (ROI) for BMD analysis. The ROI for the metacarpus (a) and the 4th caudal vertebra (upper ROI) and 5th caudal vertebra (lower ROI) (b) are shown by red lines.

\section{MATERIALS AND METHODS}

\section{Animals and experimental design}

Twenty-four multiparous pregnant Holstein dairy cows in late-lactation (during 199-319 days in milk and 131-157 days of gestation on day 0) reared in seven private dairy farms around Obihiro City, Hokkaido, were examined. The cows were divided into control and DFA groups. Cows in the control group $(n=12)$ were fed total mixed ration (TMR) formulated with the nutrients for maintaining milk yield of 32.0 to $36.0 \mathrm{~kg}$ /day ad libitum in each farm. Cows in the DFA group (n=12) were fed daily with TMR plus supplementation of 200 g/day of DFA III pellets (Nippon Beet Sugar Manufacturing Corporation Ltd., Tokyo, Japan) from day 1 to 28 . The DFA III pellets contained 20\% DFA III; therefore, the DFA group was fed $40 \mathrm{~g}$ of DFA III per day. The daily allowance (mean values \pm standard error of the mean $[\mathrm{SEM}]$ ) of $\mathrm{Ca}$, phosphorus $(\mathrm{P})$, magnesium $(\mathrm{Mg})$ and the dietary cation-anion difference (DCAD) in the control and DFA III groups, respectively, were $11.0 \pm 0.22$ and $10.9 \pm 0.23 \mathrm{~g} / \mathrm{kg} \mathrm{DM} ; 4.3 \pm 0.06$ and 5.1 $\pm 0.32 \mathrm{~g} / \mathrm{kg} \mathrm{DM} ; 2.6 \pm 0.06$ and $2.5 \pm 0.07 \mathrm{~g} / \mathrm{kg}$ DM [15]; $16.9 \pm 0.8$ and $16.2 \pm 0.9 \mathrm{mEq} / 100 \mathrm{~g}$ [1] from day 1 to 28 , respectively. All cows were in good clinical condition during the experimental period ( 28 days).

There were no significant differences between the control and DFA III groups in the mean values \pm SEM for parity, body weight, daily milk yield, or body condition [8]. These values were $3.17 \pm 0.07$ and $3.17 \pm 0.09 ; 829 \pm 4.57$ and $829 \pm 4.27 \mathrm{~kg} ; 38.1 \pm 0.59$ and $38.3 \pm 0.66 \mathrm{~kg} ; 3.29 \pm 0.01$ and $3.29 \pm 0.01$, respectively.

Evaluations of BMD were performed, and blood, milk, and urine samples were collected five times at 1-week intervals for 28 days (i.e., on days $0,7,14,21$ and 28 of the experiments).

The study protocol and experimental design were approved by the Committee for the Care and Use of Laboratory Animals of Obihiro University of Agriculture and Veterinary Medicine (approval number, 28-160).

\section{Evaluation of bone mineral density (BMD)}

Based on previous studies, BMD was evaluated by means of radiographic absorptiometry (RA) of the right metacarpal bone and the 4th and 5th caudal vertebrae after feeding $[12,18]$. Briefly, the metacarpus was exposed to X-rays at $70 \mathrm{kV}, 1.0 \mathrm{mAs}$, and film focus distance (FFD) $70 \mathrm{~cm}$, and the caudal vertebrae were exposed at $70 \mathrm{kV}, 0.5 \mathrm{mAs}$, and FFD $70 \mathrm{~cm}$. An aluminum (Al) step wedge was exposed simultaneously during each radiographic examination as a reference standard, and imaging was performed using a computed radiography unit (FCR XL-2; Fujifilm, Tokyo, Japan). Digital imaging data were transferred to an image processing program (ImageJ, Rasband, W.S., ImageJ, U.S. National Institutes of Health, Bethesda, MD, U.S.A., https:// imagej.nih.gov/ij/, 1997-2016) for analysis of the BMD of the bones in each region of interest (ROI). The ROI for the metacarpal bone was selected to include the cancellous bone at the level of the distal foramen (Fig. 1a), and the ROIs for the caudal vertebrae were selected to include the cortical and cancellous bone (Fig. 1b). The BMD values of the metacarpus and caudal vertebrae were calculated as described in previous studies $[12,18]$.

\section{Blood biochemical analysis}

Blood samples for biochemical analysis were obtained from the jugular veins using blood collection tubes (Insepack II-D,

Tokuyama Sekisui Industrial Co., Tokushima, Japan; and VenojectII, Terumo Corp., Tokyo, Japan) after feeding. The samples were 


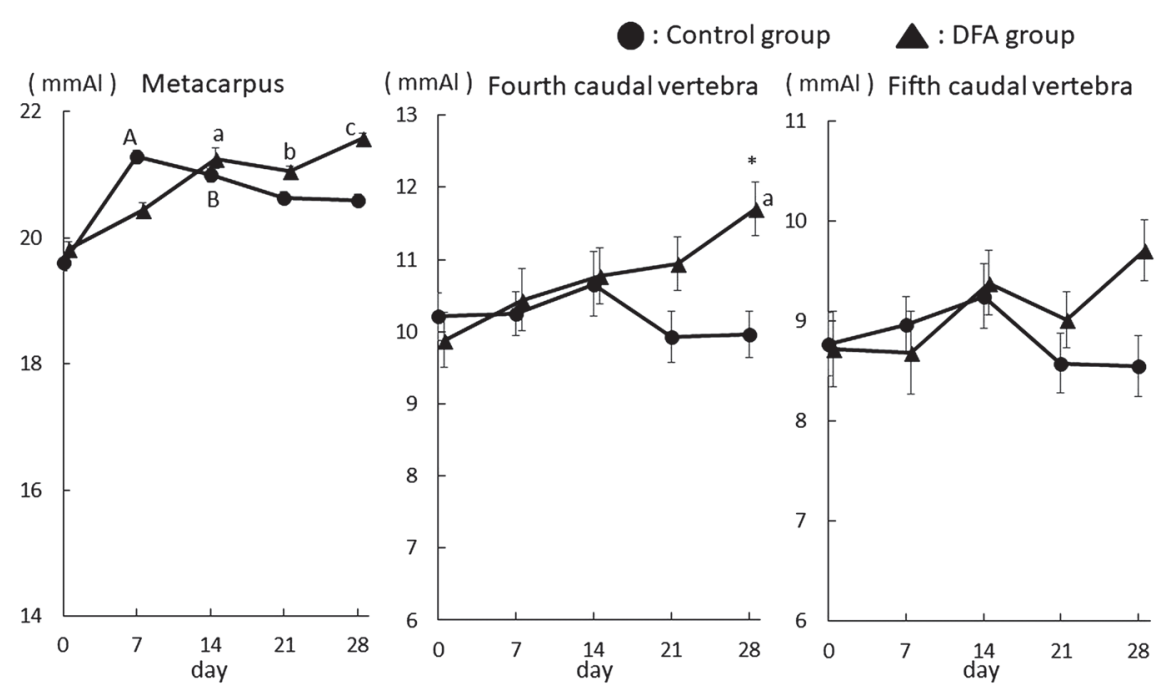

Fig. 2. Changes in the bone mineral density (BMD) of the metacarpus, 4th caudal vertebra, and 5th caudal vertebra during the experimental periods ( 0 to 28 days) in the control group $(\bullet: n=12)$ and the DFA group $(\boldsymbol{\Delta}: \mathrm{n}=12)$. Values are shown as means \pm SEMs. Significant differences between the control and DFA groups at each point are shown: ${ }^{*} P<0.05$. Letters A and B indicate statistically significant differences $(P=0.0001$, $P<0.01$, respectively) from the value on day 0 in the control group. Letters a, b, and c indicate statistically significant differences $(P<0.01$, $P<0.05$ and $P<0.0001$, respectively) from the value on day 0 in the DFA group.

centrifuged, and the serum and plasma were frozen at $-30^{\circ} \mathrm{C}$ and $-80^{\circ} \mathrm{C}$, respectively, until analysis.

Serum Ca concentrations were measured using an automatic biochemical analyzer (AU680, Beckman-Coulter, Brea, CA, U.S.A.). Serum bone-specific alkaline phosphatase (BAP) activity was measured using a chemiluminescent enzyme immunoassay (CLEIA) kit (Access Ostase, Beckman-Coulter). Tartrate-resistant acid phosphatase isoform 5b (TRAP5b) activity was measured using a fluorometric method by adding naphthol-ASBI-phosphate as a substrate [20,37]. Serum undercarboxylated osteocalcin (ucOC) and osteocalcin (OC) concentrations were measured using electrochemiluminescence immunoassay (ECLIA) kits (Picolumi-ucOC, Eisai, Tokyo, Japan; and Elecsys, Roche Diagnostic, Switzerland). The ucOC-to-OC (ucOC/OC) ratio was calculated for analysis [10].

\section{Analysis of milk Ca concentration}

Milk samples were collected during the morning milking session at each farm and stored at $-30^{\circ} \mathrm{C}$ until analysis. Milk Ca concentration was measured using inductively coupled plasma spectroscopy (ICPE-9000, Shimadzu, Kyoto, Japan). In this assay, 1 $\mathrm{m} l$ of milk sample was mixed with $0.5 \mathrm{~g}$ of cellulose (Wako Pure Chemical Industries Ltd., Osaka, Japan), incinerated in a muffle furnace for $2 \mathrm{hr}$ at $600^{\circ} \mathrm{C}$, and digested using hydrochloric acid according to the standard analytical method [5].

\section{Urinary biochemical analysis}

Urine samples were collected aseptically using a urethral catheter (Fujihira Industry, Tokyo, Japan) after feeding, and the samples were stored at $-30^{\circ} \mathrm{C}$ until analysis. Urinary $\mathrm{Ca}$ and creatinine (Cre) levels were measured using the automatic biochemical analyzer (AU680); then, the urinary Ca-to-Cre ratio $(\mathrm{Ca} / \mathrm{Cre})$ was calculated.

\section{Statistical analysis}

Statistical analysis was performed using SAS Enterprise Guide version 7.1 (SAS Institute Inc., Cary, NC, U.S.A.). All numerical data are shown as means \pm SEM. The data were analyzed in the mixed model (PROC MIXED) using the minimum variance quadratic unbiased estimation method (MIVQUE) for repeated measures. The model was assessed with fixed treatment effects (control vs. DFA), day $(0,7,14,21$ and 28$)$ and day $\times$ treatment interaction. The random effect of cows nested within the treatment and farm status was set as a covariate. The ante-dependence (ANTE) covariate structure was utilized, and Tukey's post-hoc comparison test was used to explore differences between groups. The level of significance was set at $P<0.05$.

\section{RESULTS}

The changes in the BMD of the metacarpus and the caudal vertebrae in the control and DFA groups during the experiment are shown in Fig. 2. The BMD of the metacarpus in the DFA group was significantly increased at days 14, 21 and 28 compared to day $0(P<0.01, P<0.05$ and $P<0.0001$, respectively). A transient elevation of the BMD in the control group was observed on day 7 ( $P=0.0001$ vs. day 0$)$, and this elevation persisted to day 14 ( $P<0.01$ vs. day 0$)$. In the DFA group, the BMD of the 4th caudal vertebra on day 28 was significantly higher than that on day $0(P<0.01)$ and higher than that of the control group on day 28 


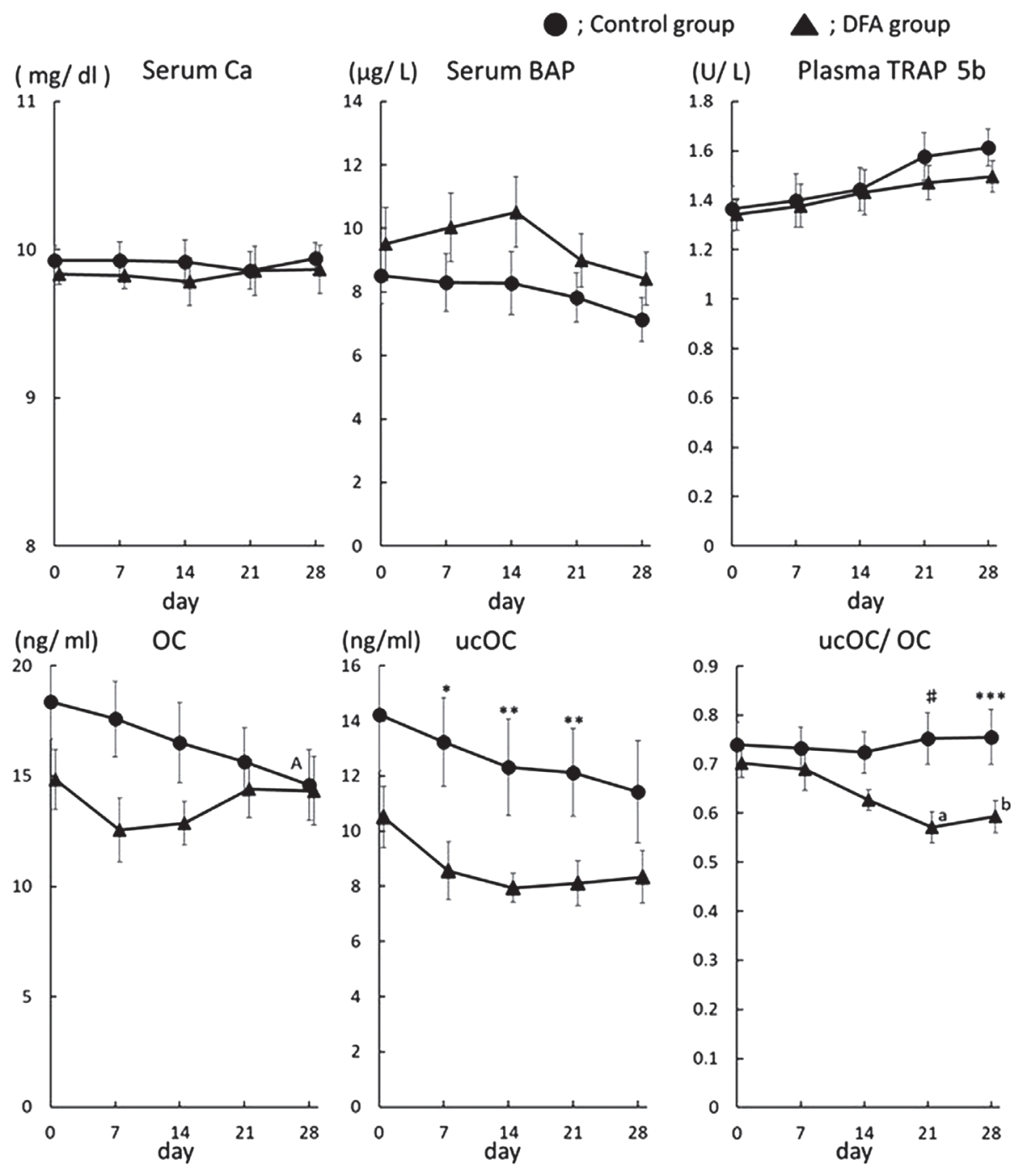

Fig. 3. Changes in the serum calcium (Ca) concentration, bone-specific alkaline phosphatase (BAP) and plasma tartrate-resistant acid phosphatase isoform $5 b$ (TRAP5b) activities, serum osteocalcin (OC) and undercarboxylated osteocalcin (ucOC) concentrations, and ucOC/OC ratio during experimental periods ( 0 to 28 days) in the control group $(\bullet: \mathrm{n}=12)$ and the DFA group $(\boldsymbol{\Lambda}: \mathrm{n}=12)$. Values are shown as means \pm SEMs. Significant differences between the control and DFA groups at each time point are shown: $* P<0.01, * * P<0.05, * * * P<0.001$ and ${ }^{\sharp} P<0.0001$. The letter A indicates a statistically significant difference $(P<0.05)$ from the value on day 0 in the control group, and the letters a and $\mathrm{b}$ indicate statistically significant differences $(P<0.01$ and $P<0.05$, respectively) from the value on day 0 in the DFA group.

$(P<0.05)$. There were no significant changes in the BMD of the 5 th caudal vertebra in either group.

The blood biochemical data on $\mathrm{Ca}, \mathrm{BAP}, \mathrm{TRAP} 5 \mathrm{~b}, \mathrm{OC}$, ucOC and ucOC/OC in both groups are shown in Fig. 3. There were no changes in the serum Ca concentrations and serum BAP and plasma TRAP5b activities in either group. However, the serum OC concentrations in the control group decreased on day $28(P<0.05$ vs. day 0$)$. Moreover, lower serum ucOC concentrations were observed on days 7, 14 and 21 in the DFA group $(P<0.01, P<0.05$ and $P<0.05$, respectively) in comparison to the control group. The serum ucOC/OC in the DFA group was also significantly decreased on days 21 and 28 compared to day $0(P<0.01$ and $P<0.05$, respectively) and lower than the serum ucOC/OC of the control group on days 21 and $28(P<0.0001$ and $P<0.001$, respectively).

Changes in the milk $\mathrm{Ca}$ concentration and urinary $\mathrm{Ca} / \mathrm{Cre}$ ratio in the control and DFA groups during the experiment are shown in Fig. 4. The milk Ca concentration in the DFA group was significantly increased on day 28 compared to day $0(P<0.05)$, and the Ca concentrations in the DFA group were higher than those in the control group on days 14, 21 and $28(P<0.01, P<0.01$ and $P<0.0001$, respectively). There were no significant changes in the urinary $\mathrm{Ca} / \mathrm{Cre}$ ratios in either group.

\section{DISCUSSION}

The present study was performed to clarify the effect of 28 days of dietary DFA III supplementation on bone Ca reserves in late-lactation dairy cows. In this study, changes in the bone Ca reserves were evaluated by measuring BMD and blood biochemical 


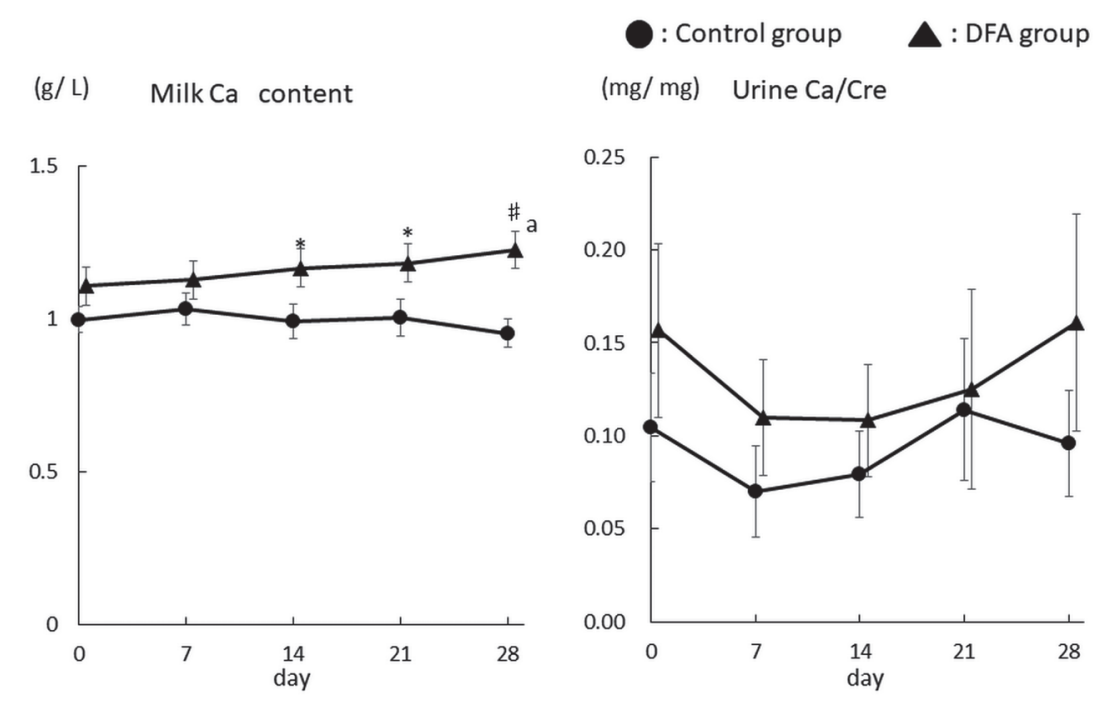

Fig. 4. Changes in milk $\mathrm{Ca}$ concentration and urine $\mathrm{Ca}$ /creatinine (Cre) ratio during experimental periods ( 0 to 28 days) in the control group ( $\bullet$ : $\mathrm{n}=12)$ and the DFA group $(\boldsymbol{\Lambda}: \mathrm{n}=12)$. Values are shown as means \pm SEMs. Significant differences between the control and DFA groups at each time point are shown: ${ }^{*} P<0.01,{ }^{\sharp} P<0.0001$. The letter "a" indicates a statistically significant difference $(P<0.05)$ from the value on day 0 in the DFA group.

bone markers.

In human medicine, RA, dual-energy X-ray absorptiometry (DXA), and quantitative computed tomography (QCT) have been used for the noninvasive measurement of BMD [4, 7]. RA measures BMD by area $\left(\mathrm{g} / \mathrm{cm}^{2}\right)$, whereas QCT measures BMD by volume $\left(\mathrm{g} / \mathrm{cm}^{3}\right)$. RA uses an X-ray beam with one energy level, whereas DXA uses two X-ray beams with different energy levels [36]. The BMD values measured by RA may reflect the effects of bone thickness and soft tissues [6]. However, it is not realistic to use these devices and equipment, which are required for DXA and QCT performance, for on-farm screening in dairy cows. On the other hand, the apparatus required for RA is portable, and it is the most practical device for measuring BMD in a dairy farm. Therefore, RA was chosen to measure BMD in this study.

In the present study, the BMD of the 4th caudal vertebra together with the metacarpus in the DFA group exhibited a significant increase on day 28 , suggesting increases in bone Ca reserves in late-lactation cows fed the diet supplemented with DFA III. These findings are similar to findings in previous studies, which have demonstrated that prolonged feeding with DFA III increased femoral mineral concentrations and BMD in ovariectomized rats [21] and a combination of dietary DFAIII and running exercises increased femoral and tibial Ca content and BMD in male rats [31].

Meanwhile, the BMD of the metacarpus in the control group was transiently increased on days 7 and 14 compared to day 0 . The BMD of the metacarpus in the DFA group was also transiently increased from day 14 to 21 . However, there were not statistically significant changes in the BMD of the 4th caudal vertebra in the both groups at each point during the experimental period. The metacarpal bone is thicker than the caudal vertebra in adult cows. Therefore, the BMD of the metacarpus in our cows may have been affected by the bone thickness [6]; thus, the RA technique seems to be preferable for measuring the BMD of the caudal vertebra in adult cows.

We also analyzed four biochemical bone markers (BAP, TRAP5b, OC and ucOC) to evaluate bone Ca reserves during dietary DFA III supplementation. BAP, a non-collagenous protein secreted by osteoblasts, is a bone formation marker that is secreted during the matrix maturation phase [11]. Furthermore, TRAP5b is an indicator of bone resorption and reflects the number of osteoclasts [27]. In the present study, there were no statistically significant differences in serum BAP and plasma TRAP5b activities between the two both groups during the experimental period. This suggests that bone formation has been accelerated at the stage of the matrix maturation stage, and osteoclastic bone resorption did not differ between the two groups.

$\mathrm{OC}$ is synthesized by osteoblasts and requires vitamin $\mathrm{K}$ in gamma-carboxylation where OC combines with hydroxyapatite [14]. Consequently, serum OC concentration is used as an indicator of bone ossification, secreted during the latter phase of bone mineralization $[24,25,28]$. In contrast, ucOC, an undercarboxylated fraction of OC, binds weakly to hydroxyapatite and is often used as a marker of osteopenia in lambs [23]. The ucOC/OC ratio in serum is often utilized as a measure of vitamin $\mathrm{K}$ status [22]. The serum ucOC concentration in the control group was higher than that in the DFA group on days 7,14 , and 21. The serum OC concentration in the control group was also decreased on day 28 compared to day 0 despite the constant serum OC concentration in the DFA group during the duration of the experiment. These changes in the serum OC and ucOC concentrations resulted in the lower ucOC/OC ratio in the DFA group in comparison to the control group on days 21 and 28 after the supplementation. This suggested that, in the DFA group, OC has been synthesized and secreted from the osteoblast because the serum OC concentration did not change significantly and ucOC/OC ratio decreased during the experiment. Therefore, we considered that DFA supplementation would stimulate the secretion of $\mathrm{OC}$, and that reflected the bone ossification. However, in the present study, the 
vitamin K status was unclear in both groups. Further studies are needed to ascertain whether DFA III supplementation affects the vitamin $\mathrm{K}$ status and serum $\mathrm{OC}$ and ucOC concentrations in late-lactation dairy cows.

In the present study, there were no statistically significant differences in the serum Ca concentrations between the two groups during the experimental period, suggesting that $\mathrm{Ca}$ homeostasis was appropriately controlled in the DFA group. Generally, an excess $\mathrm{Ca}$ ingested in a pregnant cow can migrate to the bone, urine, milk, and fetus [26]. In the present study, the milk Ca concentration in the DFA group was increased on day 28 although the urinary Ca/Cre ratio in DFA group did not significantly change during the experiment. The milk Ca concentrations on days 14, 21 and 28 in the DFA group were higher than those in the control group at each time point. During the course of this study, the gestation periods of our cows were maintained between 159 and 184 days. As a result, the Ca requirements of the fetuses were considered to be negligible because, during the first 190 days of the gestation period, pregnant cows do not need very much Ca for their fetus [2]. Therefore, the excess Ca that was absorbed from the intestine, promoted by DFA III supplementation, was excreted by the mammary gland rather than the kidney.

Although the reason for this preference was not specified in this study, one possible explanation for this phenomenon is the involvement of calciotropic hormones, such as calcitonin (CT). CT is secreted from the thyroid C-cells in response to high Ca diet ingestion [3,17], which lowers circulating Ca levels by suppressing osteoclast activity in the bones and increasing the amount of $\mathrm{Ca}$ excreted in the urine via calcitonin receptors (CTR) [17]. Bone and kidney are well-known tissues where CTR exists, whereas this receptor is expressed in the mammary glands of pregnant rats [35]. In dairy cows, there is little information on the distribution of CTRs in the kidneys and mammary glands. Further study is needed to explain the excretion of Ca from the kidney and mammary gland of late-lactation dairy cows with DFA III supplementation.

In summary, the present study revealed that dietary supplementation with DFA III for 28 days increased the BMD and decreased serum ucOC/OC ratio in late-lactation dairy cows. These observations indicate that the replenishment of bone Ca reserves can be enhanced by dietary DFA III supplementation. Additionally, DFA III supplementation may stimulate Ca secretion into milk, suggesting that the excess of $\mathrm{Ca}$ absorbed from the intestine shifted to the bone and mammary glands. Further investigations are necessary to clarify the mechanism underlying the effects of dietary DFA III supplementation on Ca and bone metabolism in latelactation dairy cows.

\section{REFERENCES}

1. Bhanugopan, M. S., Fulkerson, W. J., Fraser, D. R., Hyde, M. and McNeill, D. M. 2010. Carryover effects of potassium supplementation on calcium homeostasis in dairy cows at parturition. J. Dairy Sci. 93: 2119-2129. [Medline] [CrossRef]

2. Clark, J. H., Beede, D. K., Erdman, R. A., Goff, J. P., Grummer, R. R., Linn, J. G., Pell, A. N., Schwab, C. G., Tomkins, T., Varga, G. A. and Weiss, W. P. 2001. Mineral requirements. p. 322. In: Nutrient Requirements of Dairy Cattle. 7th ed., National Academy Press, Washington, D.C.

3. Cooper, G. W., Schwesinger, W. H., Ontjes, D. A., Mahgoub, A. M. and Munson, P. L. 1972. Stimulation of secretion of pig thyrocalcitonin by gastrin and related hormonal peptides. Endocrinology 91: 1079-1089. [Medline] [CrossRef]

4. Cosman, F., Herrington, B., Himmelstein, S. and Lindsay, R. 1991. Radiographic absorptiometry: a simple method for determination of bone mass. Osteoporos. Int. 2: 34-38. [Medline] [CrossRef]

5. Cunniff, P. 1996. AOAC official methods 985.01 In: Official Methods of Analysis of AOAC International, 16th ed., AOAC International, Arlington.

6. Donald, E. T. 2012. Introduction to radiographic interpretation. pp. 74-75. In: Textbook of Veterinary Diagnostic Radiology, 6th ed., Elsevier Saunders, St. Louis.

7. Ebbesen, E. N., Thomsen, J. S., Beck-Nielsen, H., Nepper-Rasmussen, H. J. and Mosekilde, L. 1999. Lumbar vertebral body compressive strength evaluated by dual-energy X-ray absorptiometry, quantitative computed tomography, and ashing. Bone 25: 713-724. [Medline] [CrossRef]

8. Edmonson, A. J., Lean, I. J., Weaver, L. D., Farver, T. and Webster, G. 1989. A body condition scoring chart for Holstein dairy cows. J. Dairy Sci. 72: 68-78. [CrossRef]

9. Goff, J. P. 2000. Pathophysiology of calcium and phosphorus disorders. Vet. Clin. North Am. Food Anim. Pract. 16: 319-337, vii. [Medline] [CrossRef]

10. Hirao, M., Hashimoto, J., Ando, W., Ono, T. and Yoshikawa, H. 2008. Response of serum carboxylated and undercarboxylated osteocalcin to alendronate monotherapy and combined therapy with vitamin $\mathrm{K}_{2}$ in postmenopausal women. J. Bone Miner. Metab. 26: 260-264. [Medline] [CrossRef]

11. John, P. B., Lawrence, G. R. and Gideon, A. R. 2002. Metastatic bone diseases. p. 1562. In: Principles of Bone Biology. 2nd ed., Academic Press, San Diego.

12. Keene, B. E., Knowlton, K. F., McGilliard, M. L., Lawrence, L. A., Nickols-Richardson, S. M., Wilson, J. H., Rutledge, A. M., McDowell, L. R. and Van Amburgh, M. E. 2004. Measures of bone mineral content in mature dairy cows. J. Dairy Sci. 87: 3816-3825. [Medline] [CrossRef]

13. Kikuchi, H., Nagura, T., Inoue, M., Kishida, T., Sakurai, H., Yokota, A., Asano, K., Tomita, F., Sayama, K. and Senba, Y. 2004. Physical, chemical and physiological properties of difructose anhydride III produced from inulin by enzymatic reaction. J. Appl. Glycosci. 51: 291-296. [CrossRef]

14. Kim, S. M., Kim, K. M., Kim, B. T., Joo, N. S., Kim, K. N. and Lee, D. J. 2010. Correlation of undercarboxylated osteocalcin (ucOC) concentration and bone density with age in healthy Korean women. J. Korean Med. Sci. 25: 1171-1175. [Medline] [CrossRef]

15. Liesegang, A., Chiappi, C., Risteli, J., Kessler, J. and Hess, H. D. 2007. Influence of different calcium contents in diets supplemented with anionic salts on bone metabolism in periparturient dairy cows. J. Anim. Physiol. Anim. Nutr. (Berl.) 91: 120-129. [Medline] [CrossRef]

16. Liesegang, A., Eicher, R., Sassi, M. L., Risteli, J., Kraenzlin, M., Riond, J. L. and Wanner, M. 2000. Biochemical markers of bone formation and resorption around parturition and during lactation in dairy cows with high and low standard milk yields. J. Dairy Sci. 83: 1773-1781. [Medline] [CrossRef]

17. Littledike, E. T. and Goff, J. 1987. Interactions of calcium, phosphorus, magnesium and vitamin D that influence their status in domestic meat animals. J. Anim. Sci. 65: 1727-1743. [Medline] [CrossRef]

18. Maetani, A., Itoh, M., Nishihara, K., Aoki, T., Ohtani, M., Shibano, K., Kayano, M. and Yamada, K. 2016. Experimental assessment of bone mineral density using quantitative computed tomography in holstein dairy cows. J. Vet. Med. Sci. 78: 1209-1211. [Medline] [CrossRef] 
19. Matsumoto, D., Takagi, M., Hasunuma, H., Fushimi, Y., Ohtani, M., Sato, T., Okamoto, K., Shahada, F., Tanaka, T. and Deguchi, E. 2009. Effects of oral administration of difructose anhydride III on selected health and blood parameters of group-housed Japanese black calves during the preweaning period. Asian-Australas. J. Anim. Sci. 22: 1640-1647. [CrossRef]

20. Matsuo, A., Togashi, A., Sasaki, K., Devkota, B., Hirata, T. and Yamagishi, N. 2014. Diurnal variation of plasma bone markers in Japanese black calves. J. Vet. Med. Sci. 76: 1029-1032. [Medline] [CrossRef]

21. Mitamura, R. and Hara, H. 2005. Prolonged feeding of difructose anhydride III increases strength and mineral concentrations of the femur in ovariectomized rats. Br. J. Nutr. 94: 268-274. [Medline] [CrossRef]

22. Nagata, Y., Inaba, M., Imanishi, Y., Okazaki, H., Yamada, S., Mori, K., Shoji, S., Koyama, H. and Okuno, S. 2015. Increased undercarboxylated osteocalcin/intact osteocalcin ratio in patients undergoing hemodialysis. Osteoporos. Int. 26: 1053-1061. [Medline] [CrossRef]

23. Pastoureau, P., Vergnaud, P., Meunier, P. J. and Delmas, P. D. 1993. Osteopenia and bone-remodeling abnormalities in warfarin-treated lambs. J. Bone Miner. Res. 8: 1417-1426. [Medline] [CrossRef]

24. Price, P. A., Poser, J. W. and Raman, N. 1976. Primary structure of the gamma-carboxyglutamic acid-containing protein from bovine bone. Proc. Natl. Acad. Sci. U.S.A. 73: 3374-3375. [Medline] [CrossRef]

25. Price, P. A., Williamson, M. K. and Lothringer, J. W. 1981. Origin of the vitamin K-dependent bone protein found in plasma and its clearance by kidney and bone. J. Biol. Chem. 256: 12760-12766. [Medline]

26. Ramberg, C. F. Jr., Johnson, E. K., Fargo, R. D. and Kronfeld, D. S. 1984. Calcium homeostasis in cows, with special reference to parturient hypocalcemia. Am. J. Physiol. 246: R698-R704. [Medline]

27. Rissanen, J. P., Suominen, M. I., Peng, Z. and Halleen, J. M. 2008. Secreted tartrate-resistant acid phosphatase $5 b$ is a Marker of osteoclast number in human osteoclast cultures and the rat ovariectomy model. Calcif. Tissue Int. 82: 108-115. [Medline] [CrossRef]

28. Sato, R., Onda, K., Kato, H., Ochiai, H., Kawai, K., Iriki, T., Kaneko, K., Yamazaki, Y. and Wada, Y. 2013. An evaluation of the effect of age and the peri-parturient period on bone metabolism in dairy cows as measured by serum bone-specific alkaline phosphatase activity and urinary deoxypyridinoline concentration. Vet. J. 197: 358-362. [Medline] [CrossRef]

29. Sato, T., Hanada, M., Ohtani, M., Nakai, T., Teramura, M., Sadoya, H., Takahashi, T. and Hongo, A. 2012. Short communication: effect of difructose anhydride III on serum immunoglobulin G concentration in newborn calves. J. Dairy Sci. 95: 5336-5339. [Medline] [CrossRef]

30. Sato, T., Kikuchi, H., Nakai, T., Sadoya, H., Hanada, M. and Okamoto, M. 2006. Effect of ruminal bacteria on degradability of difructose anhydride III. Nihon Chikusan Gakkaiho 77: 395-399 (in Japanese with English abstract). [CrossRef]

31. Shiga, K., Hara, H., Okano, G., Ito, M., Minami, A. and Tomita, F. 2003. Ingestion of difructose anhydride III and voluntary running exercise independently increase femoral and tibial bone mineral density and bone strength with increasing calcium absorption in rats. J. Nutr. 133: 4207-4211. [Medline] [CrossRef]

32. Takagi, M., Hasunuma, H., Matsumoto, D., Obi, T., Takase, K., Ohtani, M., Sato, T., Watanabe, U., Okamoto, K., Tanaka, T., Tshering, C. and Deguchi, E. 2011. Effects of daily oral administration of difructose anhydride III on health status, blood parameters and faecal shedding of coliform bacteria of Japanese black calves during the pre-weaning period. Anim. Nutr. Feed Technol. 11: 147-158.

33. Teramura, M., Nakai, T., Itoh, M., Sato, T., Ohtani, M., Kawashima, C. and Hanada, M. 2015. Difructose anhydride (DFA) III promotes calcium absorption from the duodenum in cattle. J. Dairy Sci. 98: 2533-2538. [Medline] [CrossRef]

34. Teramura, M., Wynn, S., Reshalaitihan, M., Kyuno, W., Sato, T., Ohtani, M., Kawashima, C. and Hanada, M. 2015. Supplementation with difructose anhydride III promotes passive calcium absorption in the small intestine immediately after calving in dairy cows. J. Dairy Sci. 98: 8688-8697. [Medline] [CrossRef]

35. Tverberg, L. A., Gustafson, M. F., Scott, T. L., Arzumanova, I. V., Provost, E. R., Yan, A. W. and Rawie, S. A. 2000. Induction of calcitonin and calcitonin receptor expression in rat mammary tissue during pregnancy. Endocrinology 141: 3696-3702. [Medline] [CrossRef]

36. Vaccaro, C., Busetto, R., Bernardini, D., Anselmi, C. and Zotti, A. 2012. Accuracy and precision of computer-assisted analysis of bone density via conventional and digital radiography in relation to dual-energy x-ray absorptiometry. Am. J. Vet. Res. 73: 381-384. [Medline] [CrossRef]

37. Yamagishi, N., Takehana, K., Kim, D., Miura, M., Hirata, T., Devkota, B., Sato, S. and Furuhama, K. 2009. Fluorometric method for measuring plasma tartrate-resistant acid phosphatase isoform 5b and its application in cattle. J. Vet. Med. Sci. 71: 1637-1642. [Medline] [CrossRef]

38. Zetterholm, R. 1978. Bone mineral changes in growing, pregnant and lactating cattle. Acta Vet. Scand. 19: 18-29. [Medline] 